\title{
Strength of Sieved Only Oil Palm Ash Foamed Concrete
}

\author{
H. Awang and M. Z. Al-Mulali
}

\begin{abstract}
Oil palm ash (OPA) is a waste material produced by countries having a blooming palm oil industry. Increasing palm oil production, the quantities of OPA continue to increase. However, its utilisation remains minimal and most of it is disposed of in landfills, causing environmental hazards. This study investigated the strength of foamed concrete incorporating sieved only OPA as a partial cement replacement. A foamed concrete mix of 1 part binder and 2 parts filler with a plastic density of $1450 \mathrm{~kg} / \mathrm{m}^{3}$ has been used. Cement is replaced by OPA at replacement levels of 25 to $65 \%$ by weight of binder. Compressive, tensile splitting and flexural strengths have been investigated at the ages of 7, 14, 28 and 56 days. A foamed concrete mix with a $25 \%$ OPA content showed superior strengths than those exhibited by the control mix, hence, producing a greener and cheaper foamed concrete.
\end{abstract}

Index Terms-Foamed concrete, OPA, strength.

\section{INTRODUCTION}

Oil palm Ash (OPA) or Palm Oil Fuel Ash (POFA) is a by-product produced by countries having a blooming palm oil industry such as Malaysia, Thailand and Indonesia. It is generated by the incineration of oil palm shell and palm oil empty fruit bunch at a temperature of $800 \mathrm{C}^{\circ}$ to $1000 \mathrm{C}^{\circ}$ as a mean of heating up the mill's boilers instead of using conventional fuels. Due to this incineration process, ash is produced at about $5 \%$ by weight of the incinerated solid fuels [1]. Malaysia alone produces around 4 million tonnes of OPA annually [2]. This number is expected to rise due to the Malaysian government's encouragement to use palm oil bio-mass as fuel for electricity production [3], [4].

OPA is a throw away product that is produced abundantly. Common practices for the disposal of this by-product were either by tipping or dumping. Hence, the waste is either spread over the premises of the mill or dumped to fill in low economic value dumps or selected types of land such as swamplands, abandoned sand quarries. Singh et al. [5] stated that the uncontrolled disposal of such waste, especially ash, will lead to the deterioration of the environment due to the fact that they are rich in organic substance. Tay and Show [6] mentioned another issue with improper disposal of oil palm ash is that the ash particles, due to their light weight, will be carried by winds creating smog in a humid day.

Foamed concrete is classified as a lightweight concrete which could be based on either mortar or a cement paste. Stable bubbles are entrapped within the mortar's matrix by

Manuscript received December 1, 2014; revised March 27, 2015. This work was supported by Universiti Sains Malaysia (USM) under the under USM RUI Grant (Ref. No. 1001 / PPBGN / 811234).

The authors are with the Department of Building Technology, School of Housing, Building and Planning, USM. 11800 Minden, Pulau Pinang, Malaysia (e-mail: hanizam@usm.my, mohammed.almulali@gmail.com). using a protein or a synthetic based foaming agent. Foam concrete has been gaining huge amounts of attention due to its high flow-ability, low self-weight, reduced aggregate consumption, controlled low strength and its admirable thermal insulation. By controlling the quantity of the foam, foam concrete could be produced to have a wide range of densities $\left(400-1600 \mathrm{~kg} / \mathrm{m}^{3}\right)$ [7]. In addition, foamed concrete is considered to be an environmental friendly material due to its minimised usage of aggregate and its high potential to incorporate waste materials [8].

Recycling of oil palm ash is receiving increasing attention because of its huge potential in improving economic benefits and environmental awareness [9]. As an alternative to oil palm ash disposal, recycling of this waste is a good alternative. Although OPA is a relatively new pozzolanic material, many studies have endeavoured on incorporating it in producing concrete as partial cement or filler replacement [10]. However, these studies enhanced the chemical and physical properties of OPA before incorporating it in the production of concrete [10]. Although these enhancements are beneficial, they do apply considerable cost [11], [12]. In addition, these further processes hinder OPA's practicality and make it confined to laboratory conditions. Furthermore, utilising OPA as a partial cement replacement has yet to be investigated. Therefore, this paper will investigate the possibility of using sieved only OPA as a partial cement replacement in producing a greener and cheaper foamed concrete mix.

\section{EXPERIMENTAL PROCEDURE}

\section{A. Materials}

The cement used is a Type I cement complying with BS EN 196 of the British Standards. Natural sand from a local river bed is used as fine sand in this study. Potable water is used and a locally produced protein based foaming agent. The foaming agent is mixed with water at a ratio of $(1: 30)$ then aerated to produce preformed stable foam having a density of $67 \mathrm{~kg} / \mathrm{m}^{3}$. Naphthalene based super-plasticiser with a PH number of 7.5 is used in the mixes with an OPA replacement. The OPA was collected from a nearby palm oil mill. The OPA was a result of incinerating palm oil biomass at temperatures exceeding $1000^{\circ} \mathrm{C}$. The collected ash was dried in an oven for 24 hours at a temperature of $105 \pm 5^{\circ} \mathrm{C}$ then sieved through a $300 \mu \mathrm{m}$ sieve. The passing through the mentioned sieve was used as cement replacement in this study. Table I shows the chemical composition of both cement and OPA alongside their physical properties.

\section{B. Mixture Proportions}

Table II shows the proportions for the foamed concrete mixes. In total, six mixes were prepared for this study. 
Foamed concrete mixes having a design plastic of $1450 \mathrm{~kg} / \mathrm{m}^{3}$ and a mix ratio of $(1: 2)$ were mixed. Alongside a control mix having cement as the binder, 5 more mixes with OPA replacing cement at levels of $25,35,45,55$ and $65 \%$ by weight of binder were prepared. A $1 \%$ dose of superplasticiser was added to the mixes containing OPA.

TABLE I: CHEMICAL COMPOSITION \& PHYSICAL PROPERTIES FOR CEMENT

\begin{tabular}{|c|c|c|}
\hline \multicolumn{3}{|c|}{ \& OPA } \\
\hline Chemical Composition (\%) & Cement & OPA \\
\hline Carbon (C) & -- & 9.31 \\
\hline Silicon Dioxide $\left(\mathrm{SiO}_{2}\right)$ & 19.98 & 66.64 \\
\hline Aluminium Oxide $\left(\mathrm{Al}_{2} \mathrm{O}_{3}\right)$ & 5.17 & 3.82 \\
\hline Iron Oxide $\left(\mathrm{Fe}_{2} \mathrm{O}_{3}\right)$ & 3.27 & 3.69 \\
\hline Calcium Oxide $(\mathrm{CaO})$ & 63.17 & 5.23 \\
\hline Magnesium Oxide (MgO) & 0.79 & 2.29 \\
\hline Sulphur Trioxide $\left(\mathrm{SO}_{3}\right)$ & 2.38 & 0.43 \\
\hline Alkalis $\left(\mathrm{Na}_{2} \mathrm{O}\right)$ & -- & 0.15 \\
\hline Loss on Ignition (LOI) & -- & 6.09 \\
\hline $\mathrm{SiO}_{2}+\mathrm{Al}_{2} \mathrm{O}_{3}+\mathrm{Fe}_{2} \mathrm{O}_{3}$ & -- & 74.15 \\
\hline Median particle size $d_{50}(\mu \mathrm{m})$ & 5.73 & 18.63 \\
\hline Specific gravity & 2.85 & 1.65 \\
\hline Loose bulk density $\left(\mathrm{kg} / \mathrm{m}^{3}\right)$ & 1180 & 833.6 \\
\hline Blaine surface area $\left(\mathrm{cm}^{2} / \mathrm{g}\right)$ & 3924 & 1952 \\
\hline
\end{tabular}

\begin{tabular}{ccccccc}
\hline \hline \multicolumn{7}{c}{ TABLE II: MiXTURE PROPORTION $\left(\mathrm{KG} / \mathrm{M}^{3}\right)$} \\
\hline \hline Mix & Cement & OPA & Sand & Water & Foam & $\begin{array}{c}\text { Spread } \\
(\mathrm{mm})\end{array}$ \\
\hline & & & & & & \\
C100 & 414.46 & 0.00 & 828.92 & 145.00 & 0.375 & 230 \\
OP25 & 310.84 & 103.61 & 828.92 & 130.58 & 0.361 & 220 \\
OP35 & 269.40 & 145.06 & 828.92 & 165.90 & 0.326 & 225 \\
OP45 & 227.95 & 186.51 & 828.92 & 186.50 & 0.301 & 220 \\
OP55 & 186.51 & 227.95 & 828.92 & 220.39 & 0.272 & 220 \\
OP65 & 145.06 & 269.40 & 828.92 & 237.11 & 0.222 & 220 \\
\hline \hline
\end{tabular}

The filler and binder (cement and OPA) are mixed in a horizontal paddle mixer having a capacity of $0.23 \mathrm{~m}^{3}$ and a speed of $40 \mathrm{r} / \mathrm{min}$. Water is added gradually to the homogeneous mix until the required spread is achieved (220 to $240 \mathrm{~mm}$ ). The consistency of the mix is checked using the Brewer test. The density of the mortar is measured by weighing a 1 litre cup of the mortar; then, the amount of foam is calculated then added to the mix. The mixer is kept rotating until no signs of foam is apparent. The resultant mix is then checked for its density which should be equal to $1450 \mathrm{~kg} / \mathrm{m}^{3} \pm 50 \mathrm{~kg} / \mathrm{m}^{3}$. The mix is then poured into moulds and then de-moulded after 24 hours. The foamed concrete samples are wrapped with polypropylene film for its curing which is a basic practice done by the industry [13].

\section{Testing Programme}

Cube specimens of $100 \times 100 \times 100 \mathrm{~mm}$ were used to test for the compressive strength of foamed concrete samples. The compressive strength test was conducted according to BS EN 12390-3 [14]. Cylinder specimens having a diameter of $100 \mathrm{~mm}$ and $200 \mathrm{~mm}$ in height were used for the tensile splitting test. The test was conducted according to BS EN 12390-6 [15]. Prism specimens with the dimensions of 100 $\times 100 \times 500 \mathrm{~mm}$ were used for the flexural test. The test was conducted according to BS EN 12390-5 [16]. Each test has been conducted at the ages of 7, 14, 28 and 56 days. The reading obtained for each of the tests at each age is the average of three specimens.

\section{RESUlTS AND DISCUSSION}

\section{A. Water and Foam Requirements}

Water requirements increased with increasing the OPA content beyond $25 \%$ even with the addition of the superplasticiser. The lowest water requirement was needed in OP25 due to the effectiveness of the super-plasticiser addition. The increased water requirement to achieve the required spread is due to the shape and nature of the OPA particle [1]. The angular and irregular shaped OPA particle would require more water to lubricate its surface. Furthermore, the OPA particle is porous in nature hence absorbs more water. Foam amounts dropped with increasing OPA content. This is due to the lower specific gravity of the OPA in comparison to that of cement. When replacing cement by OPA, the mortar's density drops, hence, requiring less foam to achieve the design plastic density. Nambiar and Ramamurthy [17] stated the same observation when replacing sand with fly ash.

\section{B. Compressive Strength}

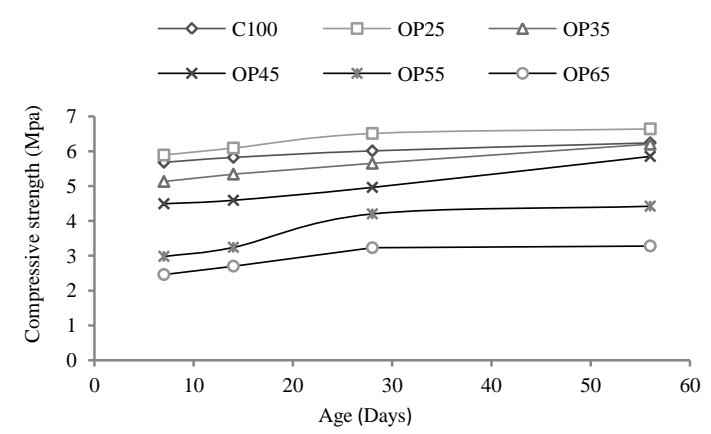

Fig. 1. Compressive strength as a function of age.

Fig. 1 shows compressive strength of the six foamed concrete mixes as a function of age. OP25 achieved higher compressive strengths than those exhibited by the C100. This is reasoned to the lower water/solids ratio required needed for the wanted consistency. This is a result of the $1 \%$ by weight of super-plasticiser addition to the mix. OP35 achieved lower strengths at earlier ages then achieved strength similar to that of the control mix at 56 days. The compressive strength reduced with the increase of OPA content beyond $35 \%$. This is due to the increased water/solids ratio which OPA mixes require and to the dilution effect which is caused by the decreased amount of cement. However, all mixes showed strength development throughout the ages hinting a pozzolanic reaction occurring. OP25 is a cost efficient foamed concrete mix due to decreased quantities of both cement and foam. It is also a more environmental friendly foamed concrete mix due to the incorporation of OPA.

\section{Tensile Splitting Strength}

Fig. 2 shows the results of the tensile splitting strength as a function of age. The results for this test followed the compressive strength. The higher tensile strength was achieved by OP25. This is due to the sufficient amount of cement and to the reduced amount of water/solids ratio in 
the mix. Increasing the OPA content beyond $25 \%$ decreased the tensile strength. This came as a result of the increasing amount of water needed with increasing OPA content. Although the tensile strengths were reduced by the addition of OPA, the tensile strengths remained higher than the minimum tensile strength required for foamed concrete which is equal to $0.17 \mathrm{MPa}[18]$.

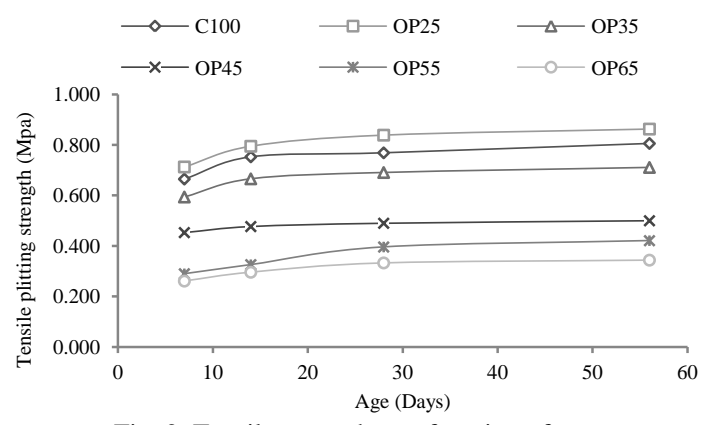

Fig. 2. Tensile strength as a function of age.

\section{Flexural Strength}

Flexural strength results are shown in Fig. 3. The same trend is followed here as the prior conducted tests. The OP25 mix achieved higher flexural strengths than that of the control mix. This is due to a denser mix which is a result of a sufficient quantity of cement and to the decreased amount of water in the mix. Increasing the OPA content beyond $25 \%$ had a negative effect on the flexural strength. However, all mixes showed flexural strength development with age indicating the existence of a pozzolanic reaction occurring within the paste of the mix.

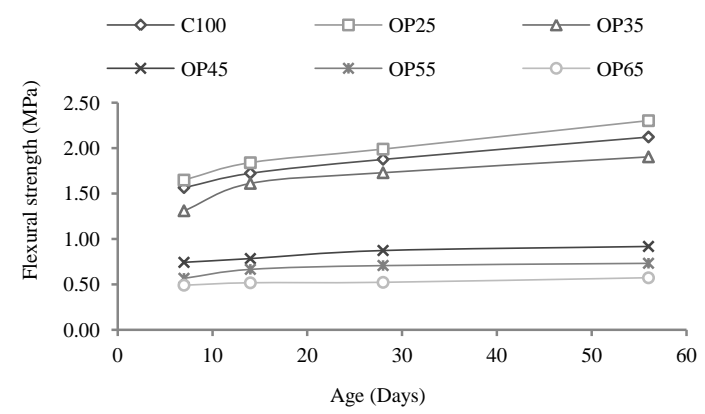

Fig. 3. Flexural strength as a function of age.

\section{E. Relationship between Compressive, Tensile Splitting and Flexural Strengths of Unground OPA Foamed Concrete}

Fig. 4 shows the relationships between compressive strength and both tensile splitting and flexural strengths. Both tensile splitting and flexural strength are strongly related to the compressive strength. An increase in compressive strength would lead to the increase of both flexural and tensile splitting strengths. The relationship between the compressive strength and both flexural and splitting tensile strength for OPA foamed concrete mixes at 28 days are best represented by the following equations:

$$
\begin{gathered}
f_{F}=0.039\left(f_{c}\right)^{2.1052} \\
f_{T}=0.058\left(f_{c}\right)^{1.4109}
\end{gathered}
$$

Both equations have a $R^{2}$ of 0.92 and 0.94 for flexural and tensile splitting strengths respectively.

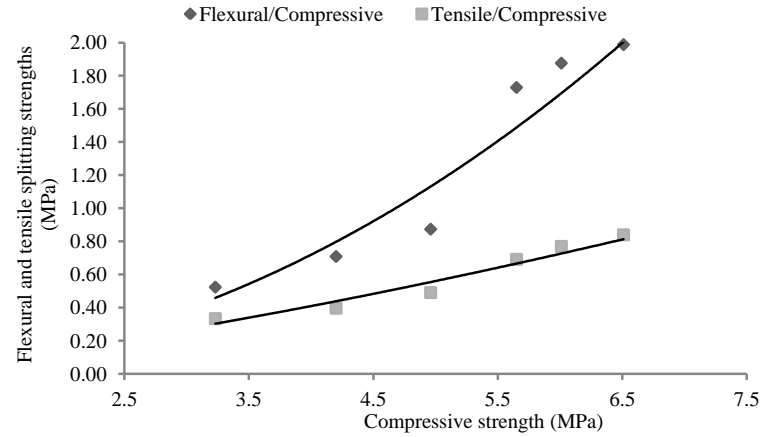

Fig. 4. Relationship between compressive strength and both flexural and tensile splitting strengths at 28 days for OPA foamed concrete mixes.

\section{CONCLUSIONS}

This study endeavoured on utilising sieved only OPA in the production of foamed concrete. A $25 \%$ replacement level of OPA with the aid of a naphthalene based superplasticiser showed superior strengths than those exhibited by the control mix. Increasing the OPA content at a replacement level exceeding $25 \%$ had a negative effect on the strength. However, all OPA foamed concrete mixes showed strength development with increasing age, hence, hinting a pozzolanic reaction occurring within the paste of the mix. Both tensile splitting and flexural strengths are strongly related to the compressive strength. Therefore, it is possible to produce a greener and cheaper foamed concrete by using sieved only OPA. It is greener because waste is used within the mix and cheaper because not only a reduction in cement is occurring but we are using a free waste and a reduced foam quantity.

\section{ACKNOWLEDGMENT}

The authors gratefully acknowledge the financial support of Universiti Sains Malaysia under USM RUI Grant (Ref. No. 1001 / PPBGN / 811234).

\section{REFERENCES}

[1] S. K. Lim, C. S. Tan, O. Y. Lim, and Y. L. Lee, "Fresh and hardened properties of lightweight foamed concrete with palm oil fuel ash as filler," Construction and Building Materials, vol. 46, pp. 39-47, 2013.

[2] K. Y. Foo and B. H. Hameed, "Value-added utilization of oil palm ash: A superior recycling of the industrial agricultural waste," Journal of Hazardous Materials, vol. 172, pp. 523-533, 2009.

[3] M. S. Umar, P. Jennings, and T. Urmee, "Generating renewable energy from oil palm biomass in Malaysia: The feed-in tariff policy framework," Biomass and Bioenergy, vol. 62, pp. 37-46, 2014.

[4] M. S. Umar, P. Jennings, and T. Urmee, "Sustainable electricity generation from oil palm biomass wastes in Malaysia: An industry survey," Energy, vol. 67, pp. 496-505, 2014.

[5] R. P. Singh, A. Embrandiri, M. H. Ibrahim, and N. Esa, "Management of biomass residues generated from palm oil mill: Vermicomposting a sustainable option," Resources, Conservation and Recycling, vol. 55, no. 4, pp. 423-34, 2011.

[6] J. H. Tay and K. Y. Show, "Use of ash derived from oil-palm waste incineration as a cement replacement material Resources," Conservation and Recycling, vol. 13, pp. 27-36, 1995.

[7] S. Wei, Z. Yunsheng, and M. R. Jones, "Using the ultrasonic wave transmission method to study the setting behavior of foamed concrete," Construction and Building Materials, vol. 51, pp. 62-74, 2014.

[8] N. Noordin and H. Awang, "Lightweight foamed concrete in construction industry," in Proc. the International Conference on 
Construction and Real Estate Management ICCRE, Penang, Malaysia, pp. 1-6, 2005.

[9] T. Kaosol, W. Tongsuwan, and S. Kaewsatain, "Recycling of oil palm ash as partial replacement of cement in concrete block productions," in Proc. the 8th Asian-Pacific Regional Conference on Practical Environmental Technologies (APRC2010) Ubonratchathani, Thailand, pp. 1-8, 2010.

[10] M. Z. Al-mulali, H. Awang, H. P. S. A. Khalil, and Z. S. Aljoumaily, "The incorporation of oil palm ash in concrete as a means of recycling: A review," Cement and Concrete Composites, vol. 55, pp. 129-38, 2015.

[11] H. Chao-Lung, B. L. Anh-Tuan, and C. C. Tsun, "Effect of rice husk ash on the strength and durability characteristics of concrete," Construction and Building Materials, vol. 25, no. 9, pp. 3768-72, 2011.

[12] R. Zerbino, G. Giaccio, and G. C. Isaia, "Concrete incorporating rice-husk ash without processing," Construction and Building Materials, vol. 25, no. 1, pp. 371-8, 2011.

[13] M. R. Jones and A. McCarthy, "Utilising unprocessed low-lime coal fly ash in foamed concrete," Fuel, vol. 84, no. 11, pp. 1398-409, 2005.

[14] Testing Hardened Concrete. Compressive Strength of Test Specimens, BSI. BS EN 12390-3-2009.

[15] Testing Hardened Concrete. TENSILE Splitting Strength of Test Specimens, BSI. BS EN 12390-6 -2009.

[16] Testing Hardened Concrete. Flexural Strength of Test Specimens, BSI. BS EN 12390-5- 2009.

[17] E. K. K. Nambiar and K. Ramamurthy, "Influence of filler type on the properties of foam concrete," Cement \& Concrete Composites, vol. 28, pp. 475-80, 2006.

[18] K. C. Brady, G. R. A. Watts, and M. R. Jones, "Specification for foamed concrete," TRL Project Report PR/IS/40/01, pp. 1-78, 2001

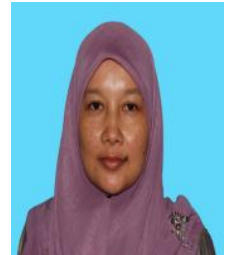

H. Awang joined USM's School of Housing, Building and Planning on 16 April 2001 as a lecturer in Building Technology Programme. She obtained her first degree from Universiti Teknologi Malaysia in civil engineering. She received her master's degree from Newcastle University and she received her $\mathrm{Ph} . \mathrm{D}$ in civil and structural engineering from Universiti Kebangsaan Malaysia. She has some years of working experience with several civil \& structural consultant, and contractor firms before joining Universiti Sains Malaysia.

She has published her academic articles in indexed journals, and presented many international and local papers in the field of engineering, building material and building construction. She is leading few research projects on lightweight foamed concrete and supervising postgraduate students by research and coursework at MSc and Ph.D. levels at the school of Housing, Building \& Planning, USM. Her specialisation lies in the area of advanced concrete materials, lightweight concrete and building construction.

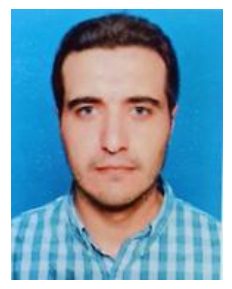

Mohammed Zuhear Al-mulali was born in Iraq, in 1980. He received his bachelor degree in civil engineering from the School of Engineering, Babylon University in 2002. He worked as a site engineer from October 2003 until February 2007. He is a member of the Iraqi union of engineers since 2003. $\mathrm{He}$ obtained his master's degree in building technology in the year 2011 from the School of Housing, Building and Planning, Universiti Sains Malaysia. Now, he is a Ph.D. candidate at the Department of Building Technology, School of Housing, Building \& Planning, Universiti Sain Malaysia. He majors in foamed concrete and its applications in the construction industry. 